\title{
Administrative Accountability of Development Planning Deliberation (Musrenbang) Implementation in Bone Regency
}

\author{
Aslinda* \\ Departemen of Public \\ Adminsitration \\ faculty of sosial science \\ Universitas Negeri Makassar \\ Makassar, Indonesia \\ aslinda@unm.ac.id
}

\author{
Fakhri Kahar \\ Departemen of Public \\ Adminsitration \\ Public Administration Department \\ Universitas Negeri Makassar \\ Makassar, Indonesia \\ fakhri.kahar@unm.ac.id
}

Muh. Lutfi

Departemen of Public Adminsitration

Faculty of Sosial Science

Universitas Negeri Makassar

Makassar, Indonesia

muhammadluthfisiraj@gmail.comm

\author{
Muh. Rizal S \\ Departemen of Public \\ Adminsitration \\ faculty of sosial science \\ Universitas Negeri Makassar \\ Makassar, Indonesia \\ rizalsuyuti@unm.ac.id
}

\begin{abstract}
The objective of this research is to determine the administrative accountability in implementing development planning deliberation (Musrenbang) in Bone Regency. This research employed descriptive qualitative approach. The data collection techniques were library research, documentation review, field research, and online data exploration. The analysis technique was an interactive model through the data collection, data condensation, data display, and verification (conclusion) stages. The results exposed that the administrative accountability of the development planning deliberation in Bone Regency was carried out very well in terms of the planning aspect by conducting initial socialization before the Musrenbang, and constructing communication with stakeholders who have interest in formulating the preparations up to the needs that will be prepared at the Musrenbang. The organizing aspect was carried out by the Agency for Regional Development (Bappeda) which organizes the entire society to be able to participate in the Musrenbang. For this aspect of mobilizing / directing was by providing opportunities for the society to participate in Musrenbang and in the implementation of ongoing Musrenbang activities, Bappeda also directs each sub-district and society to provide all contribution on the design of development programs which needed by Bone regency, and for the aspect of supervision with the monitoring by Bappeda starting from the preparation, socialization, to the results stage of the Musrenbang.
\end{abstract}

Keywords: Accountability, Administrative, Musrenbang

\section{INTRODUCTION}

The government apparatus is the bearer of the state substantial duty in general and the regions in particular in managing all matters of implementing regional programs. As explained by the Secretariat of the Vice President (2012) the professional apparatus becomes the backbone of the bureaucratic reform implementation, it is including the realization of the vision and mission of the regional government depending on the management of the government apparatus, as all the regional programs including the Regional Development Planning program depends on accountability and integrity of the village officials for the lowest government apparatus. Law No. 32 Year 2004 article 1 paragraph 2 government apparatus is the organizer of government affairs by the regional government and Provincial Assembly according to the principle of autonomy and co-administration (mide bewine), with the broadest possible autonomy principle in the system and principles of the Unitary State of the Republic of Indonesia as intended in the 1945 Constitution of the Republic of Indonesia [1].

It is expected that the administrative accountability study in carrying out some regional government affairs, in the field of development, can fulfill the interests of the society, this is vital considering that this problem is part of the realization of public affairs in public administration studies. Although in reality, development problems are often related to "the minimum availability of regional budgets, lack of access to participation from various parties in development planning, and a lack of responsibility from government officials to carry out their main functions [2].

The problem of development in a region, especially in the Bone regency, can be overcome, if the local government is able to create a real accountability model. The local government must be able to explain how much its policy achievements have been in the welfare of the people. Government accountability must also be interpreted and formulated in explaining the phenomena that occur and challenge the role of the government which has tended to create mal administration in society, rather than being oriented to "public accountability". The public bureaucracy is considered to be accountable when they are assessed 
objectively by the society and can be accountable for all their actions to which party the power and authority they have comes from [3]. Moreover, Schacter further describes that the implementation of accountability in local government at least refers to 2 (two) main objectives. First, political purpose, namely accountability in minimizing abuse of power. Second, operational objectives, namely procedural accountability in ensuring the government to be effective and efficient in running local government [4].

To support the circulated performance of the Bone Regency government in regional development, a good administration is needed as an effort to increase the expected quality of organizational performance. The intended administration is an overall process which goal is to complete a work with a better goal. Basically, administration functions to determine organizational goals and formulate general policies, while management functions to carry out activities that need to be carried out in order to achieve goals within the boundaries of the formulated general policy [5][6]. In the implementation process, the administration and management have certain tasks that must be carried out independently. These tasks are commonly interpreted as administrative and management functions. Terry explains that administrative and management functions are "functions of planning, organizing, directing and supervising" [7].

The administrative accountability process in implementing the Development Plan Deliberation (MUSRENBANG) is an important indicator to see how serious the government is in the regions, especially in the Bone Regency area in formulating various demands or society support. Meanwhile, in its practice administrative accountability in implementing Musrenbang in various regions is still not optimal, this is indicated by the existence of the role of the society which is expected in the regions is not fully included in Musrenbang activities, parties involved in Musrenbang activities are not reliable enough to create public accountability effective and efficient.

Observing the stated phenomena above, it confirms that administrative accountability by local governments is needed in fulfilling the interests of its people. Therefore, in order to realize the vision of each region, it is necessary to have clear administrative accountability from the government, especially in organizing Musrenbang. Decentralization has an impact on a more democratic system level. However, in its implementation, central government intervention in the regions is often unavoidable, and the aspect of supervision of the bureaucratic apparatus is still weak so that the impact has implications for the basic rights services of society which are still neglected in the current era of democratization.

\section{METHODOLOGY}

This research was conducted in Bone regency, South Sulawesi Province, this location was chosen purposively. With the consideration of the regional condition that shows the existence of various problems related to administrative accountability in organizing Musrenbang which are considered not optimal. This research employed a descriptive with a qualitative approach. The data collection techniques are carried out by library research, documentation review, field research, and online data exploration. The analysis technique used was an interactive model through the stages of data collection, data condensation, data display, and verification (conclusion) [8] [9].

\section{RESULT AND DISCUSSION}

The process of implementing the Musrenbang cannot be separated from the responsibility of the Bone Regency government, it is the Agency for Regional Development (Bappeda) as the main committee and facilitator in formulating the policies for determining programs that will be brought to the sub-district level and village level. Administrative accountability for organizing the Musrenbang in Bone Regency will be seen from the administrative aspects and principles of organizing the Musrenbang, as follows:

a) Planning

The results of the research found that the implementation of administrative accountability in organizing Musrenbang in Bone Regency at the planning stage has been carried out well, this is indicated by the socialization stage process of all plans made by Bappeda. The form of planning is also carried out by identifying in advance in determining the people who will be involved in the organizing committee of the Musrenbang, and an analysis is also carried out by looking at all the shortcomings and strengths of each development policy program that has been completed in the previous year or is currently running in the current year. Moreover, this planning is considered to be good, because the Musrenbang organizing committee is doing the formulation of the policy by carefully calculating the Regional Government Budget and considering all the negative possibilities that can occur in each designed alternative policy program[10].

The implementation of the development planning process is vital to achieve the expected results. Organizing the Musrenbang requires careful, systematic and measured planning so that Musrenbang activities can truly achieve the expected direction. In this globalization era, planning must rely more on the rational and systematic procedures and not only on intuition and feelings (presumtive). The interview result by Muh Zuhdi as the Head of the Bone regency Regional Development Planning and Evaluation Division (July 23, 2019) that "We feel it is important that planning can move the organization wheels in the development program. So far, we have carried out planning on every development program policy which will later be followed up in Regency Musrenbang activities ".

Basically the regional government of Bone regency, in this case is Bappeda as the organizing committee for the regency Musrenbang, has made good planning by identifying all development activity programs that have been running in previous years and after that formulating the development programs is considered highly needed currently by the society and Bone Regency government. Thus, Bappeda of Bone regency and the other stakeholders involved will arrange priority scales or select the sequences in terms of the importance of a development policy objective, target or program that will be offered and delivered on the Musrenbang activities. An interview with Andi Dolla, one of the village heads in Kahu sub-district (July 24, 2019) stated that "We are fully aware that there are many obstacles encountered in determining planning in formulating any development policy 
program, this is the lack participation of Musrenbang committee in providing input to be used as ideas or considerations in formulating the plans that will be implemented later ".

The planning which carried out by Bappeda in identifying all problems and shortcomings in each development program that has been running will be communicated to the interested stakeholders with the purpose that each program that will be designed will have accuracy to the needs of the society and Bone regency. This it is also a form of administrative accountability carried out by Bappeda as the organizer of the Musrenbang. Lalolo that one of the indicators in accountability is "the accuracy and completeness of information relating to ways of achieving the goals of a program"[11].

The planning activities for the implementation of the Musrenbang for Bone regency carried out by Bappeda are also inseparable from looking at the existing local government work plans and analyzing all work designs from the village apparatus work unit, this can be seen as the flow of the planning process in the implementation of the regency Musrenbang.

Figure 1. Planning flow of Musrenbang in Bone Regency

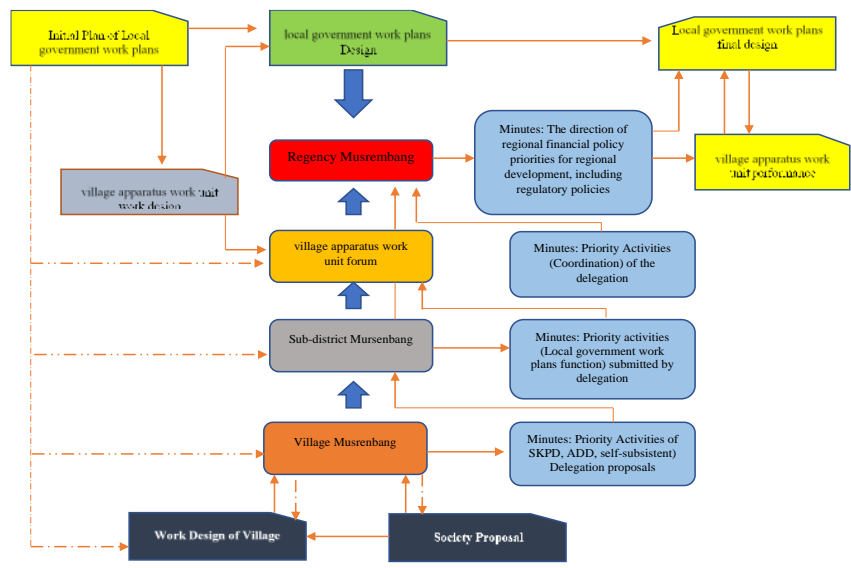

Planning in regional development is considered as a broad matter since it includes numerous interests such as to achieve the objectives that have been planned by the development team. Then, in order to make the development directed to a good and correct way and have standard guidelines. Systematica planning will help the controlling process so if there is something needs to be evaluated it can be carried out properly and clearly. Planning also has various objectives, which are very significant for organizational life, with the existence of development planning through the regency Musrenbang activities, it is certainly expected to produce various formulations of policy programs that can provide change and progress for a region.

Stephen Robbins and Mary Coulter stated several planning goals, first to provide direction for both leaders and subordinates. With a plan, subordinates can identify what they have to achieve, with whom they must work together and what must be done to accomplish organizational goals. Without a good plan, organizational lines and individuals may work independently, so this will result on the less efficient of organizational work [12]. It is also known that in administrative accountability from the planning aspect, the material used when implementing Musrenbang activities is not only considered, but also how Bappeda plans properly all human resources to pay attention to participatory principles by encouraging all interested parties to be involved and provide positive contribution in organizing Musrenbang, because the success of Musrenbang activities is determined by the level of society participation.

It is not easy to maximize the plan in the implementation regency Musrenbang but is not an impossible matter. There must be an experienced special team in this matter, such as selecting competent people in their fields, reading the Draft Budget for each program so that costs and budgets are not misused and etc.

\section{b) Organizing}

The importance of good organization in arranging by forming a working relationship between people by dividing tasks, authorities, responsibilities in detail according to fields and parts of cooperation in a harmonious and smooth way to achieve the objectives.

From the results of the research it concludes that administrative accountability in organizing Musrenbang in Bone Regency seen from the aspect of organizing has been carried out well, this is indicated by the formation of a committee structure that has accommodated all levels of society elements and a clear division of tasks and authority to all the committee members.

The results of the interview by Muh Zuhdi as the Head of the Bone Regency Regional Development Planning and Evaluation Division (July 23, 2019) clarified that "one form of organization carried out by Bappeda in preparation for the regency Musrenbang is by making a committee consists of the regency government, sub-district government and village governments, as well as several society leaders. After the committee is formed, then tasks and responsibilities are divided to each section/field in order to make each activity plan in the implementation of the regency Musrenbang can be run well".

An illustration was obtained that the understanding of Bappeda as the organizer of the Musrenbang for Bone Regency regarding the stages that need to be taken in organizing can be carried out by the organization. The organizing process consists of three stages, namely: 1) Details of all work tasks that must be carried out by each committee in the accomplishment of Musrenbang activities, 2) The division of the workload into the activities that can logically be carried out by everyone. The division of work should not be too difficult so that it can be completed, 3) Procurement and development of work mechanisms, so there is work coordination between each line of committee into an integrated and harmonious unit.

This coordinating mechanism will support members of the organizing committee for Musrenbang to comprehend the goals of the organization and reduce inefficiency and conflict. The results of the interview with Saharuddin (on July 24, 2019) stated that: "In its principle, the regency government which is coordinated through Bappeda in organizing the regency Musrenbang has been carried out optimally and well where Bappeda and other stakeholders have clearly conveyed all related information to the achieve the goals of the designed policy program ". 
The interview by Muh Zuhdi the Head of the Bone Regency Regional Development Planning and Evaluation Division (July 23, 2019) stated that "So far Bappeda has attempted to organize the society participation level to be involved in regency Musrenbang activities by inviting them, but there are also some communities who have been invited but they did not come".

The organizing effort by Bappeda of Bone regency from the figure. 1 is a form of great responsibility presented by Bappeda to develop Bone regency by conducting socialization to the sub-district with the intention of conveying to the society the plan for implementing the Musrenbang as well as inviting the society to provide input and teach several society leaders to be able to attend the Musrenbang activitiy. Therefore, in order to accomplish the goals of the regency Musrenbang by being implemented effectively and efficiently, it requires the involvement of all interested parties, especially the society by distributing duties and responsibilities to the parties involved.

The organizing that by Bappeda for human resources is also carried out by organizing the facilities and infrastructure resources that will be used in the implementation of the Musrenbang and the use of facilities and infrastructure is also very crucial to be regulated because without the existence of maximum facilities and infrastructure such as work materials ( computers, printers, photocopies, scans) that can be used by the committee to work, as stated by Winardi (2003), defines organizing as the act of cultivating effective behavioral relationships between people, so that they can work together efficiently and thus obtain personal satisfaction in terms of carrying out certain tasks in certain environmental conditions in order to achieve certain goals or objectives. In its implementation, the organization of Musrenbang in Bone regency has reflected the spirit of deliberation which is participatory and dialogical, although it sometimes still emphasizes on the formal administrative aspects which means that the program have to be implemented.

The results of this research also showed that the organization conducted by Bappeda in organizing Musrenbang is also carried out on the several study formulations as follows. 1. Formation of Deliberation Organizing Team (TPM) at the sub-district and village level 2. Formation of Regency Consultative Guidance Teams by TPM in several sub-districts 3. Technical preparation for the implementation of Regency Deliberations in each sub-district and village, 4. Participatory and dialogical assessment of subdistricts and villages in several sub-districts. This formulation is evidence that Bappeda has carried out its duties in an accountable manner.

\section{c) Mobilization/Implementation}

The implementation of administrative accountability for the Musrenbang in Bone regency, seen from the implementation aspect, has been well implemented, this is indicated that head of Bappeda can mobilize all his subordinates to prepare and carry out regency Musrenbang activities successfully. Basically, the management by Bappeda has attempted to fulfil direction to members of the organization. However, this is not well understood by other members of the organization. This was stated by Zuhdi as Head of the Regional Development Planning and Evaluation Division of Bone Regency (July 23, 2019) stated that: "the form of mobilization that we do in implementing the regency Musrenbang is to provide direction related to the main tasks and responsibilities of each participant in the Musrenbang organizer and also the stake holders involved in the activities,". Saharuddin as Head of the Tanete Riattang sub-district (24 July 2019) explained that "The important in the form of mobilization that has been fulfil by Bappeda so that the regency Musrenbang can run well is to give orders to all local government working unit of sub-district and village to seek all information needed in future development planning ".

Observing the various data obtained, it is assumed that Bappeda of Bone regency has made efforts to make coordinated approaches both in preparation to the Musrenbang which definetely will have a positive influence on the success of the regency Musrenbang activities. The form of mobilization / implementation is also understood that the purpose the mobilization is to motivate all members of the Musrenbag participants to do their duties and responsibilities properly. There are several pointers for achieving efficient motivation in the management, namely trying to make people feel important, try to recognize the differences of each individual, be a good listener, avoid debates, respect / understand the feelings of others, use words - the right words to invite others to work hard, do not try to dominate, give clear and complete instructions and do effective supervision.

Bappeda in Bone regency has made efforts to engratf work spirit in every Musrenbang participant. Thus, the direction by management must adhere to several principles, namely: a). The principle leads to the goal (the main purpose of the direction appears to be the principle which states that the more effective the direction process, the greater the contribution of subordinates to the effort to achieve the goal. Direction cannot stand alone, which means that in doing the function of direction, it is necessary to get support / assistance from other factors such as: planning, organizational structure, adequate worker, effective supervision and the ability to increase the knowledge and abilities of subordinates), b). The principle of harmony with goals (people work to meet their needs which may not be the same as organizational goals.

Bappeda in Bone regency, which is known have the task of taking care of all the preparation and implementation of regency Musrenbang activities, obviously this is not easy, but with great enthusiasm and high responsibility of Bappeda, the success of Musrenbang activities in 2018 can be carried out well and successful. Moreover, the regency Musrenbang activities organized by Bone Regency received an award from the Governor of South Sulawesi in 2019.

The directions by Bappeda in the process of organizing Musrenbang for Bone regency are; 1). Orientation (how to give direction by providing necessary information so the activities can be fulfilled properly) 2). Orders (requests from management to the sub-ordinate to carry out or repeat certain activities in certain circumstances) 3). Delegation of authority by delegating part of the authority they have to the subordinates). From the method of direction by Bappeda, the purpose is every decided policy formulation can actually have clear targets on the needs of the society and every decision that has been made, it is then published to the public either through direct delivery by the head of sub-district to the society or through printed media such as newspapers and online media.

The accountability the Musrenbang implementation has gone through the process of opening public access to decision 
information which is the indicator of accountability value, as stated [13] stated one of the accountability models is "Opening public access to decision information.and the complaint mechanism". Direction is an aspect of human relations in management that binds subordinates to be willing to understand and contribute effective and efficient labor to achieve goals. In management administration, this direction is very complex because beside to dealing with humans, it also involves the various behaviors of the humans themselves [14]. Humans with a variety of different behaviors, have different views and life patterns.

With the mobilization/direction properly by Bappeda, especially in mobilizing the society to participate in attending and participating in Musrenbang activities with the purposes that all the aspirations of the society can be expressed in the deliberation process. Besides, other mobilization by Bappeda were also seen during the ongoing Musrenbang process, where the form of this movement such as asking each sub-district and society to talk and to provide all the needed development program designs and last but not least, Bappeda was able to play a role in directing each participant to obey all the rules that have been set by the organizing committee of the Musrenbang, so the implementation of the Musrenbang of Bone regency can run well.

\section{d) Supervision}

Based on the results of the research on administrative accountability of Musrenbang implementation in Bone regency, from the aspect of supervision, it is considered to have done well, this is indicated by the monitoring of Bappeda from the preparation stage, implementation to the socialization stage of the Musrenbang results. In carrying out control activities over the implementation of Musrenbang in Bone regency, the head of Bappeda checking, matching, and making sure that the activities are in accordance with the determined plan and the goals. The interview with Zuhdi as the Head of the Regional Development Planning and Evaluation Division of Bone Regency (July 23, 2019) stated that "The supervision that we carry out is in the form of monitoring to what extent the stages of preparation for Musrenbang activities until the stage of implementing these activities meet the targets or achievements that have been planned beforehand, so that with this supervision every activity can be evaluated on how much it is right on target".

Saharuddin as Head of the Tanete Riattang sub-district (24 July 2019) also emphasized that "the form of supervision by Bappeda on the implementation of the Musrenbang is shown by the presence of the head of Bappeda and controlling every stage or process of the Musrenbang and besides, the form of evaluation by Bappeda is by giving reflection to all Musrenbang participants about the lack in each program that was made during the previous Musrenbang as well as evaluate every program proposal given by Musrenbang participants".

From the various statements above, it illustrates that Bappeda has monitored the implementation of Musrenbang which aimed at controlling the Musrenbang process and Bappeda also evaluates every program proposal which put forward by Musrenbang participants. The supervison function has not yet answered the overall objectives of the organization. Supervision is a process to ensure that organizational and management goals are achieved [15]. Management supervision is a systematic effort to establish standards of implementation with planning objectives, compare the real activities with planning objectives, compare the real activities with predetermined standards, determine and measure deviations and take corrective actions to ensure that all organizational resources are used properly effective and efficient in achieving organizational goals.

Supervision by Bappeda is not only in the process of implementing the Musrenbang, but this supervision is also to see the participation of the Bone regency society in attending Musrenbang activities. Based on the results of the data report regarding the percentage level of society participation in attending the Musrenbang activities in the last three years, it can be seen in the graph below.

Figure 2. Participation level in Attending Musrembang of Bone Regency

Participation Level in Attending Musrenbang of Bone Regency

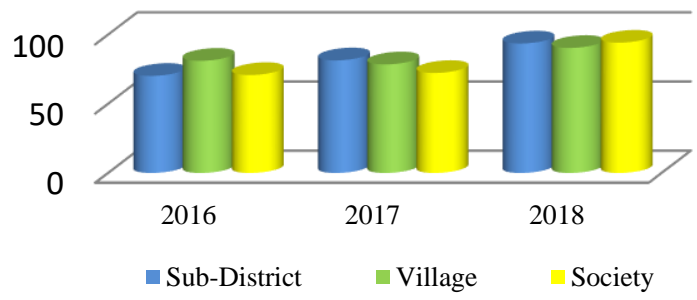

Source: Bappeda of Bone Regency 2019

From the graphic above, it can be seen that the last three years from 2016 to 2018 there has been a good increase in society participation to participate in the Musrenbang which can be seen in 2016 only reached 80 percent and in 2018 it reached 90 percent and of course this proves that Bappeda is quite successful in evaluating the progress of society participation in participating in Musrenbang by optimizing the socialization to all regencies, sub-districts and also to the society regarding the importance of musrenbang.

A supervision is very crucial to be carried out intensively by the leader of the organization, because without the supervision the objectives of the organization in doing its program cannot be maximally realized. The form of accountability that Bappeda Bone regency takes in implementing its supervision of Musrenbang is also carried out by monitoring the socialization by the sub-district government to the society on the results of the Musrenbang.

The supervision carried out by Bappeda in organizing the Musrenbang is not only on the implementation, but this supervision has also been fulfilled by Bappeda during the preMusrenbang where with monitoring in the pre-Musrenbang, obviously Bappeda will be able to evaluate to what extent the level of society participation and also the level of participation to provide input to the Musrenbang regency implementation plan. With a good control, evaluation and follow-up system by Bappeda during the pre-Musrenbang, the impact of implementing the Musrenbang in 2018 is in accordance with the data that has been drawn in the research results which show that the level of society participation to be involved in Musrenbang increases from the previous year. 
Moreover, the form of supervision by Bappeda to make the implementation of Musrenbang can run well and done according to the expectations and plans, thus Bappeda asks several parties to do supervision and escort starting from the neighborhood level to the regency level so the Musrenbang proposed by society is not just a ceremonial event but the proposed program is also felt in terms of real development. The implementation of Musrenbang in Bone Regency so far, starting from program preparation to the implementation cannot be separated from government accountability and transparency at various levels, accountability and supervision so far starting from funding, programs, processes, legal, and outcomes from the process of implementing Musrenbang so far Bone regency. Bappeda and the Bone Government all work together with the village, sub-district and regency governments in supervising the Musrenbang.

The Development Planning Deliberation (Musrenbang) is held annually before entering the next year's budget. The Musrenbang regency begins with Musrenbang at the village level and then the sub-district level. In principle, proposals are compiled and submitted in stages starting from the neighborhood, Village and Regency levels. Proposal data from all villages / sub-districts that have been collected will be considered and deliberated, the results of these sub-district deliberations are set in a single document in form of a list subdistrict proposal activities to be proposed at the Musrenbang on the regency level.

\section{CONCLUSION}

Based on the results of the research, it concludes that the administrative accountability of Musrenbang implementation in Bone regency was considered to have been implemented very well, as from the all aspects assessed starting from planning, organizing, mobilizing, and supervising which all are considered to have been carried out accountably.

From the conclusions above, some suggestions that can be recommended are as follows: 1) Bone Regency Government provides wider and fairer opportunities for the society to actively participate and provide information about the importance of active society participation so that development and potential in Bone Regency can be maximally utilized .2) It is recommend in decision-making, the involvement of stakeholders can be increased quantitatively for every representation of women and youth groups to be involved in Musrenbang activities, 3) The quality of information conveyed to Musrenbang participants should be improved, especially regarding the clarity of issues and strategic problems faced, priorities programs, activities and availability of funding, so that each Musrenbang regency activity can be carried out more effectively and efficiently.

\section{REFERENCES} OF SHARIA MUNICIPAL BOND ISSUANCE FROM AN INDONESIAN LEGAL PERSPECTIVE," 2018.

[2]
Valk, and A. Van Den Brink, "The participating government: Shifting boundaries in collaborative spatial planning of urban regions," Environ. Plan. C Polit. Sp., vol. 35, no. 1, pp. 147-168, 2017.

[3] J. Widodo, Good governance: telaah dari dimensi akuntabilitas dan kontrol birokrasi pada era desentralisasi dan otonomi daerah. Insan Cendekia, 2001.

[4] R. B. Purba and A. M. Amrul, "Penerapan Sistem Akuntansi Keuangan Daerah Transparansi Publik dan Aktivitas Pengendalian Terhadap Akuntabilitas Keuangan pada Badan Keuangan Daerah Kabupaten Tanah Datar," J. Ris. Akunt. dan Bisnis, vol. 18, no. 2, pp. 140-152, 2018.

[5] Y. Guo, Q. N. Huy, and Z. Xiao, "How middle managers manage the political environment to achieve market goals: Insights from C hina's state-owned enterprises," Strateg. Manag. J., vol. 38, no. 3 , pp. 676-696, 2017.

[6] C. J. Koliba, J. W. Meek, A. Zia, and R. W. Mills, Governance networks in public administration and public policy. Routledge, 2018.

[7] R. Briandana and M. Irfan, "Broadcasting Management: The Strategy of Television Production Configuring for Sustainability in the Digital Era," Int. J. English Lit. Soc. Sci., vol. 4, no. 6, 2019.

[8] M. B. Miles and A. M. Huberman, Qualitative data analysis: An expanded sourcebook. sage, 1994.

[9] A. Upe, "Metode Penelitian Sosial: Filosofi dan Desain Praktis," Kendari Lit. Inst., 2016.

[10] I. Farhana, "Assessing budgetary management of local government in Aceh, Indonesia," 2019

[11] G. A. García-Mireles, M. Á. Moraga, F. García, C. Calero, and M. Piattini, "Interactions between environmental sustainability goals and software product quality: A mapping study," Inf. Softw. Technol., vol. 95, pp. 108-129, 2018.

[12] A. P. J. Schotter, R. Mudambi, Y. L. Doz, and A. Gaur, "Boundary spanning in global organizations," J. Manag. Stud., vol. 54, no. 4, pp. 403-421, 2017.

[13] B. B. Siagian, M. Maryunani, R. K. Sakti, and D. B. Santoso, "Efficiency and Effectiveness Analysis of Village Financial Management (VFM)(Case Study Asahan Regency)," Int. J. Soc. Local Econ. Gov., vol. 2, no. 2, pp. 136-151, 2016.

[14] T. Thoma-Lürken, M. H. C. Bleijlevens, M. A. S. Lexis, L. P. de Witte, and J. P. H. Hamers, "Facilitating aging in place: A qualitative study of practical problems preventing people with dementia from living at home," Geriatr. Nurs. (Minneap)., vol. 39, no. 1 , pp. 29-38, 2018.

[15] E. Demerouti, M. Van den Heuvel, D. Xanthopoulou, L. Dubbelt, and H. J. Gordon, "Job resources as contributors to wellbeing," Routledge companion to wellbeing Work, pp. 269-283, 2017. 